\title{
Numerical Taxonomy of Phylloplane Bacteria Isolated from Lolium perenne
}

\author{
By B. AUSTIN* AND M. GOODFELLOW \\ Department of Microbiology, The Medical School, \\ The University, Newcastle upon Tyne $N E_{\mathrm{I}}{ }_{7} R U$ \\ AND C. H. DICKINSON \\ Department of Plant Biology, The University, \\ Newcastle upon Tyne NEI $7 R U$
}

(Received 27 July 1977; revised I5 September 1977)

\begin{abstract}
Phenetic data on over 600 heterotrophic bacteria from green leaves of Lolium perenne \$24 were collected and analysed using numerical taxonomic methods. Marker strains representing 60 taxa were included in the analyses. At similarity levels of $80 \%$ or above, $74 \%$ of the isolates were recovered in six major and 45 minor phena. Four of the major phena were equated with the taxa Listeria grayi/murrayi, Pseudomonas fluorescens, Staphylococcus saprophyticus and Xanthomonas campestris; the two unidentified phena contained pink, Gram-negative rods with polar flagella. Xanthomonads and pink chromogens formed high populations in May, xanthomonads and pseudomonads in July, xanthomonads in September and listeriae and staphylococci in October. It seems that despite the spatial proximity of leaves, litter and soil, each of these habitats contains independent bacterial communities with specific properties.
\end{abstract}

\section{INTRODUCTION}

The absence of satisfactory isolation methods and problems of classification and identification have hampered investigations of the bacterial flora of leaf surfaces. Workers have mainly used methods designed for the study of soil and litter micro-organisms and have classified bacteria into groups based upon differential characters of dubious value (Goodfellow, Austin \& Dawson, 1976a). Identification using standard diagnostic schemes is also of limited value, for few strains can be identified beyond the genus level and others not at all (Dickinson, Austin \& Goodfellow, 1975). It is now being appreciated that leaf surfaces have their own chemical and physical characteristics and may support unrecognized bacterial taxa. The lack of systematic studies on the composition of the phylloplane flora has hindered ecological work (Leben \& Daft, I965; Austin, Dickinson \& Goodfellow, 1977).

Chromogenic bacteria, known to be numerically dominant in the phylloplane of many temperate plants, have often been classed together on the basis of a few morphological, biochemical, nutritional or pigmentation properties (Goodfellow et al., I976a). Such monothetic classifications are not satisfactory for the identification of isolates giving the same response to the 'key' characters but differing widely in other properties and they make comparisons between different investigations difficult. Thus, it is not always easy to distinguish between strains of Cytophaga, Erwinia, Flavobacterium, Pseudomonas and

* Present address: Department of Microbiology, University of Maryland, College Park, Maryland 20742, U.S.A. 
Xanthomonas and other yellow-pigmented bacteria frequently associated with plant matter. High populations of xanthomonads have been reported from Lolium perenne and Trifolium repens leaves (Stout, 1960; Dickinson et al., 1975), flavobacteria from Pinus and grass leaves (Stout, 1958, 1960, 1961) and Erwinia herbicola from leaves of many Gramineae and Leguminosae (Last \& Warren, 1972). Classifications based on pigmentation are particularly suspect for numerical phenetic surveys have shown that several different types of yellow chromogens exist (McMeekin, Stewart \& Murray, 1972; Goodfellow, Austin \& Dickinson, $1976 b$ ).

Numerical phenetic methods have successfully classified bacteria isolated from large mixed populations found in aquatic habitats (Reichelt \& Baumann, 1973), in the rhizosphere (Graham, 1964) and in deciduous litter and mineral soil (Soumare, Losfield \& Blondeau, 1973; Hissett \& Gray, 1974) and have proved sensitive enough to distinguish taxa that would otherwise be put together because of current weaknesses in classification (Goodfellow, I969; Goodfellow, Austin \& Dickinson, I976b). Numerical phenetic data also allow an objective choice of strains for comparative systematic and ecological investigations. Thus, representative soil isolates from clusters defined by Lowe \& Gray (1972) were subsequently used in growth and competitive interaction work carried out in sterile soil (Lowe \& Gray, I973a, $b$ ).

In our previous studies bacteria were taken from healthy green leaves of Lolium perenne using a modified dilution plate procedure and over 600 randomly chosen isolates were identified using standard diagnostic schemes (Dickinson et al., I975). The predominant flora was provisionally identified to the genera Chromobacterium, Corynebacterium, Pseudomonas and Xanthomonas, but over $20 \%$ of the strains remained unidentified. In a pilot numerical taxonomic study, I 33 of the 600 isolates were randomly selected, examined for 73 unit characters and recovered in five clusters defined at or above the $80 \%$ similarity level (S level) (Goodfellow et al., I976a). Given the success of the orientation study, all of the phylloplane isolates were examined for additional characters, and the data were analysed using numerical methods.

\section{METHODS}

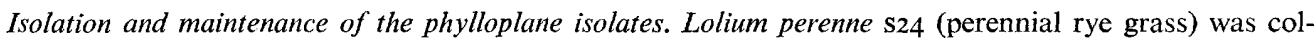
lected from a moderately grazed pasture at Cockle Park Farm, Morpeth, Northumberland (Ordnance Survey grid reference NT2I79I7) and dilution plates were prepared as described earlier (Dickinson et al., 1975). The glucose yeast extract agar (GYEA) plates, prepared from samples collected on a seasonal basis, were incubated at $25{ }^{\circ} \mathrm{C}$ for 9 days. Six hundred and fifty bacterial colonies were randomly chosen from plates containing between 30 and 300 colonies and subcultured on to slopes of GYEA. Following further incubation for 7 days at $25^{\circ} \mathrm{C}$, stained smears were examined using Hucker's modification of the Gram stain (Hucker \& Conn, 1923) and pure cultures were maintained on GYEA slopes at $5{ }^{\circ} \mathrm{C}$ and subcultured every 8 weeks. During the isolation and testing procedures 29 strains were lost. The history of the remaining $62 \mathrm{I}$ isolates is shown in Table $\mathrm{I}$.

Reference strains. The 67 reference cultures (Table 2) were maintained as above.

Collection of data. Each strain was examined for 135 unit characters (Tables 3 and 4). Media were inoculated from 5-day-old GYEA cultures and were incubated at $25^{\circ} \mathrm{C}$ for 14 days unless otherwise stated. The tests were generally carried out once but were repeated when inconclusive results were obtained. Many of the tests used have been described elsewhere (Goodfellow et al., 1976b); details of the remainder are given below.

Colony and micromorphology. Colony morphology was observed on GYEA plates after 5 days' incubation and pigmentation on GYEA supplemented with skimmed milk $(5 \%, \mathrm{w} / \mathrm{v})$ after 3 days. Fluorescein and pyocyanin pigments were detected on the media of King, Ward \& Raney (1954). Bacterial size was determined from smears stained by Hucker's modification of the Gram stain (Hucker \& Conn, 1923) and scored as small ( $<2 \mu \mathrm{m}$ long) or large ( 2 to $5 \mu \mathrm{m}$ long). The presence of mycelium, densely staining intracellular areas and pleomorphism were also observed.

Biochemical and degradative tests. Oxidation of ethanol to acetic acid (Shimwell, Carr \& Rhodes, 1960) was determined after 7 days' incubation, and the indole (method 2), methyl red and Voges-Proskauer tests (O'Meara's method) were examined after 3,5 and 7 days respectively using the methods described 
Table I. Test strains isolated from the phylloplane of Lolium perenne $\mathbf{5} 24$

\begin{tabular}{|c|c|c|c|}
\hline \multirow[b]{2}{*}{ Date of isolation } & \multicolumn{2}{|c|}{ No. of strains isolated } & \multirow{2}{*}{$\begin{array}{l}\text { No. of } \\
\text { isolates }\end{array}$} \\
\hline & Leaf $2 / 5^{*}$ & Leaf $3 / 6^{*}$ & \\
\hline I6 May I973 & $53(\mathrm{~A} \dagger)$ & $47(\mathrm{~B} t)$ & 100 \\
\hline I I July I 973 & $125(\mathrm{C})$ & $\mathrm{I} 25$ (D) & 250 \\
\hline 5 September 1973 & $75(\mathrm{E})$ & $75(\mathrm{~F})$ & 150 \\
\hline 31 October 1973 & $70(\mathrm{G})$ & $5 \mathrm{I}(\mathrm{H})$ & 121 \\
\hline & & & 621 \\
\hline
\end{tabular}

* The second and third leaves were sampled, except on 31 October, when the fifth and sixth leaves were used.

$\dagger$ Code allocated to each sample series.

by Cowan \& Steel (1965). Lactose fermentation was recorded after 5 days' incubation on MacConkey agar (Oxoid $\mathrm{CM}_{7}$ ); where colonies were naturally red or pink, MacConkey broth (Oxoid $\mathrm{CM}_{5}$ ) was used. Degradation of cellulose and urea were detected after 28 days' incubation by the methods of Stanier (1942) and Rustigan \& Stuart (1941) respectively.

Tolerance tests. The ability of strains to grow on MacConkey agar and at $\mathrm{pH} 4.5$ (Lemco broth, Oxoid $\mathrm{CM}_{15}$ amended with I $\mathrm{M}-\mathrm{HCl}$ ) was recorded after 7 days' incubation.

Coding of characters. The data were reduced to 135 mutually exclusive binary character states. Twelve characters with no differentiating value were eliminated and the final $n \times t$ matrix contained data for 688 organisms and 123 unit characters.

Computer analysis. The data were examined using the simple matching coefficient $\left(S_{\mathrm{SM}}\right.$; Sokal \& Michener, 1958), which includes both positive and negative matches, and sorted similarity matrices were obtained using unweighted average linkage clustering (UPGMA) (Sneath \& Sokal, 1973). The homogeneity of the defined clusters was verified using the Jaccard coefficient $\left(S_{J}\right.$; Sneath, 1957) which counts positive matches only.

Identification of defined phena. Phena not containing reference strains were identified as far as possible using the diagnostic tables of Cowan \& Steel (1965), keys in Bergey's Manual of Determinative Bacteriology (Buchanan \& Gibbons, 1974) and the keys of Gordon, Haynes \& Pang (1973).

\section{RESULTS}

\section{Examination of data by the matching coefficient $\left(S_{\mathrm{SM}}\right)$}

At the 80 to $85 \% \mathrm{~S}$ level, $456(74 \%)$ of the phylloplane bacteria and $17(25 \%)$ of the reference strains were recovered in 5I phena (Fig. I). The 17 reference strains helped in the identification of phena $3,6,8,24,28,42$ and 44 ; some of the remaining phena were identified using the standard schemes mentioned above. Six major phena $(I, 3,6,7$, I 6 and 44$)$, each containing at least $10(\mathrm{I} \cdot 6 \%)$ of the isolates, were recognized from their various characteristics (Table 3).

\section{Characteristics and identification of the major phena}

Phenon I contains I I pink chromogens which could not be identified using the diagnostic schemes. The strains were Gram-negative, polarly flagellate rods, about $3 \mu \mathrm{m}$ long, forming small ( $\mathrm{I}$ mm diam.), round, shiny, pink colonies on GYEA (Table 3). Glucose was attacked oxidatively, or not at all, and most strains decarboxylated arginine, lysine and ornithine, utilized malonate, degraded tributyrin but were oxidase-negative, non-proteolytic, did not reduce nitrate, and grew at $10{ }^{\circ} \mathrm{C}$ but not at $5{ }^{\circ} \mathrm{C}$. $\mathrm{L}(-)$-Arabinose, calcium lactate, capric acid, ethanol, $\mathrm{D}(-)$-galactose, $\mathrm{D}(-)$-glucose, glycerol, sodium acetate, sodium citrate, sodium fumarate, sodium gluconate, sodium glutamate, sodium malate, sodium malonate, sodium pyruvate and sodium succinate were utilized as sole carbon sources (Table 3 ). Pink chromogens with similar properties to those outlined above have been reported from leaf surfaces and identified as Mycoplana rubra, Protaminobacter ruber and Vibrio extorquens (Billing, I976; de Vries \& Derx, 1953).

Phenon 3 contains $\mathrm{I} 22$ isolates and Xanthomonas campestris NCPPB528, X. begoniae 


\section{Table 2. Reference strains}

\section{Taxon}

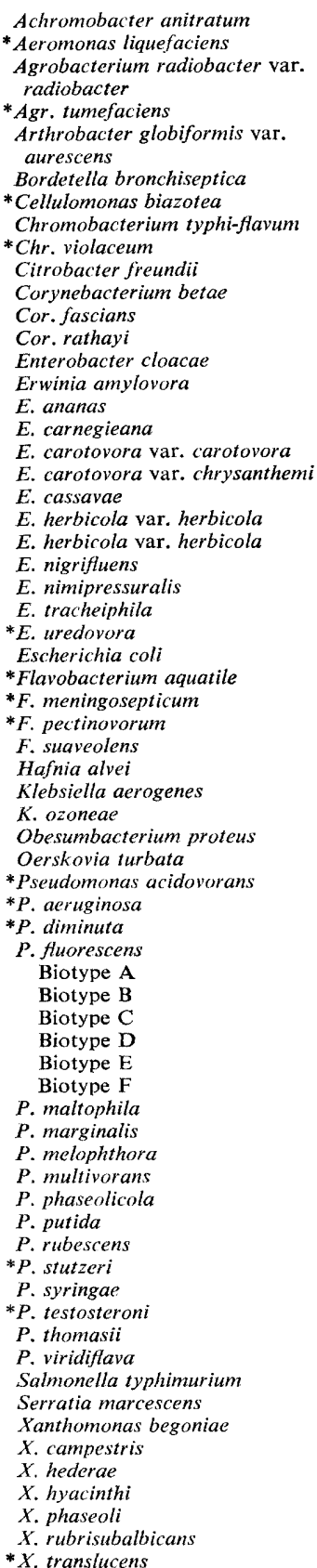

Strain

designation/sourcet

NCIB9OI9

NCMB 87

NCPPB2406

NCIB8 150

NClB89I 2

$\mathrm{NCTC} 452$

$\mathrm{NClB} 8077$

NCTC938 I

NCTC9757

NCTC607 I

NCPPB 375

NCPPB 1488

NCPPB797

NCIBIOIOI

NCPPB 595

ICPB-EAI 33

ICPB-EC I 86

NCPPB3I 2

NCPPB5I 2

ICPB-ECII

NCPPB 656

NCPPB 657

NCPPB 564

ICPB-ENI

ICPB-ET5

NCPPB 800

NCTC 8620

$\mathrm{NCIB} 8694$

NCTC10016

NCIB9O59

$\mathrm{NCIB} 8992$

Emslie-Smith, PN

NCTC8172

NCTC505I

NCIB8770

Lechevalier, 891

NCIB968 I

$\mathrm{NCIB} 8295$

NCTC8545

Sneath, D123

Sneath, DI087

Sneath, DI 25

Sneath, DI26

Sneath, DI27

Sneath, Di 28

NClB9204, NCTCIO257

NCPPB 667

$\mathrm{NCPPB} 42$

NCIB908 5

$\mathrm{NCPPB} 52$

CCEBS2O

$\mathrm{NCIB} 8768$

NCTCIO457

NCPPB 281

NCPPB 1969

NCTC 10893

NCPPB 602

NCTC57IO

Laboratory culture

NCPPB2226

NCPPB 528

NCPPB 2336

NCPPB 599

NCPPB $38 \mathrm{I}$

$\mathrm{NCPPBI027}$

NCPPB973
Isolated from

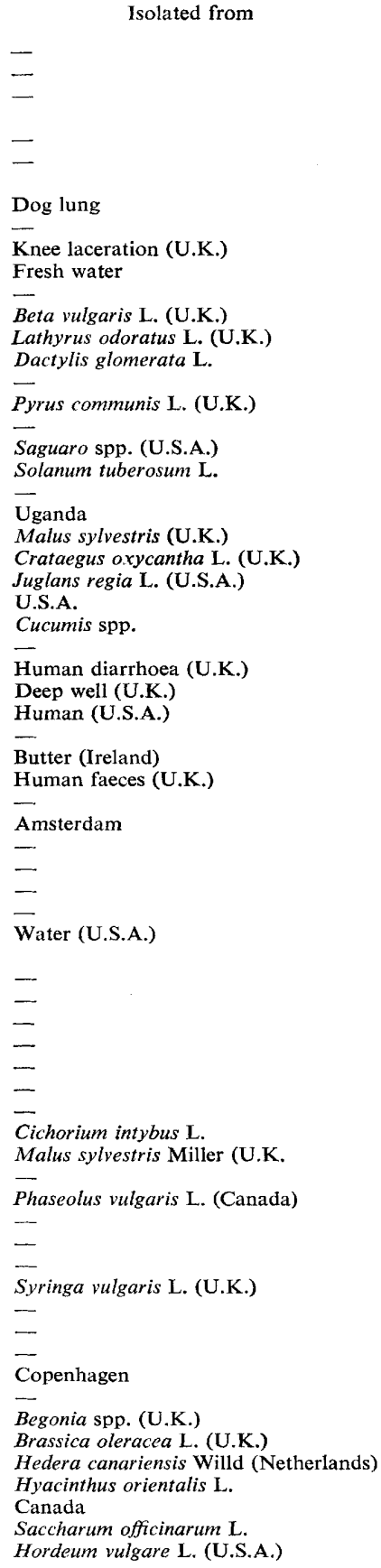

* Type strain.

$\uparrow$ Sources. Culture collections outside the U.K.: CCEB, Culture Collection of Entomogenous Bacteria, Prague, Czechoslovakia; ICPB, International Collection of Phytopathogenic Bacteria, California, U.S.A. Others: Dr A. H. Emslie-Smith, Department of Microbiology, University of Newcastle upon Tyne; Dr M. P. Lechevalier, Institute of Microbiology, Rutgers University, U.S.A.; Professor P. H. A. Sneath, Department of Microbiology, University of Leicester. 
Percentage similarity Phenon No. of Identity

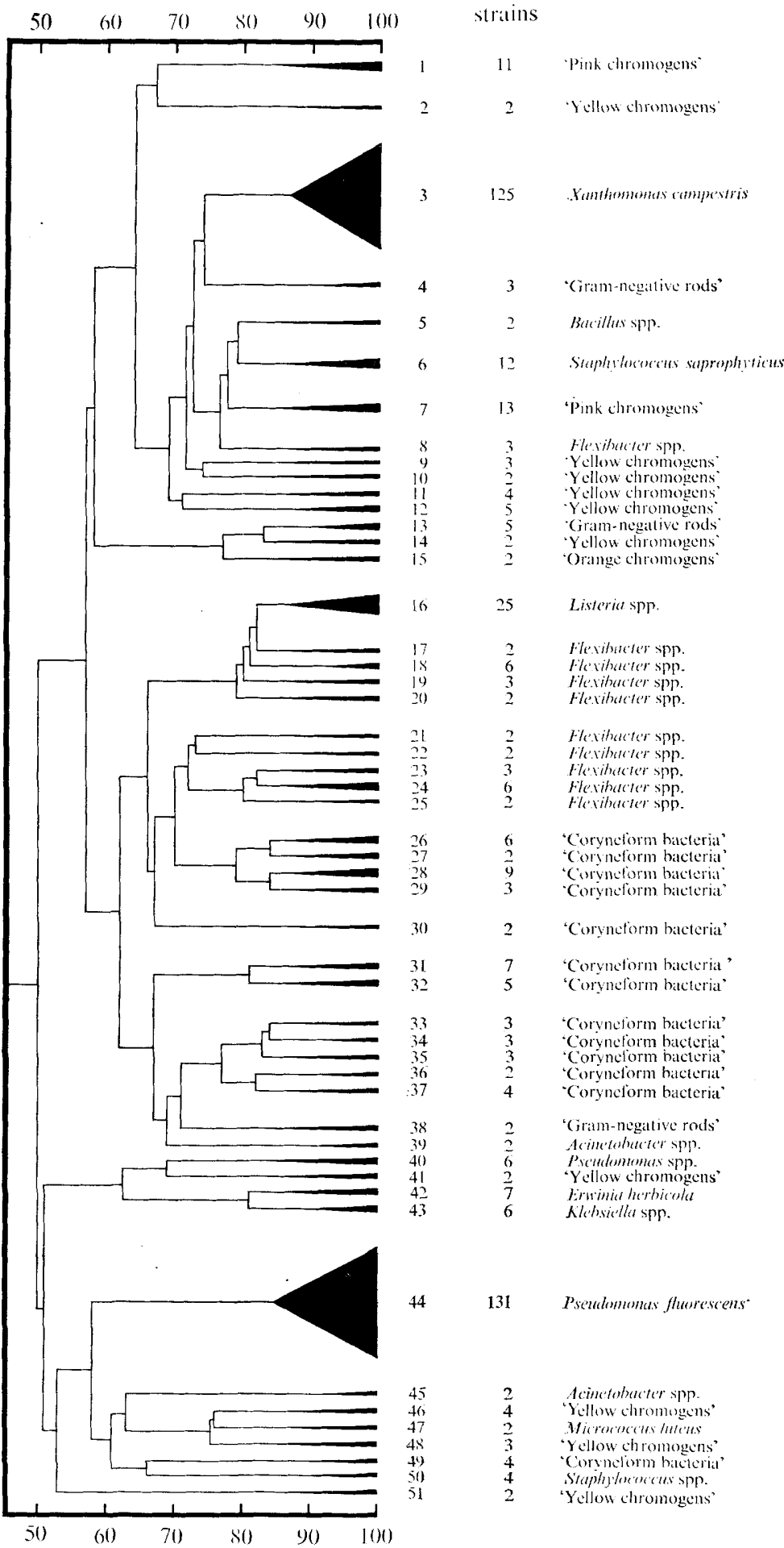

Fig. I. A simplified dendrogram showing the relationship between clusters based on the $S_{\mathrm{SM}}$ coefficient and unweighted average linkage clustering (UPGMA). 
Table 3. Characteristics of the major phena as percentages of positive reactions

Phenon number and name

\begin{tabular}{|c|c|c|c|c|}
\hline $\mathrm{I}$ & 3 & 6 & 7 & 16 \\
\hline 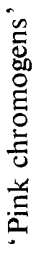 & 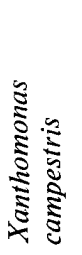 & 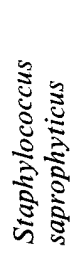 & 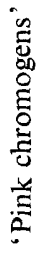 & 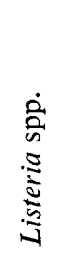 \\
\hline I I & 125 & I 2 & 13 & 25 \\
\hline
\end{tabular}

Colonial characters:

No. of strains $\quad \ldots$

Minute $(<$ I mm)

Mucoid

Levan produced

Colonies, white

Colonies, cream

Colonies, pale yellow

Colonies, deep yellow

Colonies, pink

Fluorescent diffusible pigment

Stained preparations:

Gram-positive

Cocci

Short rods $(<2 \mu \mathrm{m})$

Long rods ( 2 to $5 \mu \mathrm{m}$ )

Petrichous flagella

Polar flagella

Motility

Intracellular areas of high staining intensity

$$
100
$$

0

$\therefore$

$\therefore$

$\therefore$

$\therefore$

100

o

Biochemical tests:

Arginine dihydrolase

Fermentative metabolism

Oxidative metabolism

Gluconate oxidation

Lactose fermentation

Lysine decarboxylase

Malonate utilization

Reduction, $\mathrm{NO}_{3} \rightarrow \mathrm{NO}_{2}$

Ornithine decarboxylase

Oxidase

Tolerance to:

MacConkey agar

pH 4.5

$\mathrm{NaCl}(2 \%, \mathrm{w} / \mathrm{v})$

$\mathrm{NaCl}(5 \%, w / v)$

$\mathrm{NaCl}(7.5 \%, \mathrm{w} / \mathrm{v})$

Growth at:

$$
\begin{array}{r}
5{ }^{\circ} \mathrm{C} \\
10{ }^{\circ} \mathrm{C} \\
37^{\circ} \mathrm{C}
\end{array}
$$

Degradation of:

Aesculin

Blood

Casein

Gelatin

Lecithinase

Starch

Tributyrin

Tween 20

Tween 80

Tyrosine

4

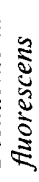

$$
\begin{array}{rrrrr}
0 & 0 & 100 & 0 & 0 \\
96 & 0 & 0 & 0 & 0 \\
74 & 0 & 0 & 0 & 0 \\
0 & 58 & 0 & 0 & 1 \\
0 & 42 & 0 & 0 & 1 \\
10 & 0 & 0 & 60 & 98 \\
90 & 0 & 0 & 40 & 0 \\
0 & 0 & 100 & 0 & 0 \\
0 & 0 & 0 & 0 & 100
\end{array}
$$$$
\begin{array}{rrrrrr}
0 & 0 & 100 & 0 & 48 & 0 \\
0 & 0 & 100 & 0 & 0 & 0 \\
0 & 100 & 0 & 0 & 100 & 100 \\
100 & 0 & 0 & 100 & 0 & 0 \\
0 & 0 & 0 & 0 & 24 & 0 \\
100 & 64 & 0 & 69 & 0 & 100 \\
100 & 64 & 0 & 69 & 24 & 100 \\
100 & 0 & 0 & 100 & 0 & 0
\end{array}
$$$$
\begin{array}{lllll}
100 & 12 & 0 & 100 & 0
\end{array}
$$$$
\begin{array}{rrrrrr}
100 & 0 & 100 & 0 & 84 & 0 \\
73 & 70 & 0 & 6 \mathrm{I} & 0 & 100 \\
0 & 0 & 0 & 0 & 0 & 98 \\
0 & 12 & 66 & 0 & 80 & 76 \\
73 & 3 & 0 & 69 & 0 & 1 \\
100 & 0 & 0 & 6 \mathrm{I} & 0 & 100 \\
0 & 18 & 66 & 23 & 8 & 0 \\
82 & 3 & 0 & 6 \mathrm{I} & 0 & 5 \\
0 & 12 & 0 & 0 & 0 & 95
\end{array}
$$$$
\begin{array}{rrrrrr}
0 & 10 & 66 & 0 & 80 & 92 \\
0 & 0 & 58 & 0 & 0 & 0 \\
0 & 58 & 100 & 8 & 100 & 100 \\
0 & 0 & 100 & 0 & 28 & 95 \\
0 & 0 & 50 & 0 & 0 & 8
\end{array}
$$$$
\begin{array}{rrrrrr}
\text { I } 8 & \text { I I } & 0 & 8 & 100 & 100 \\
100 & 64 & 0 & 46 & 100 & 100 \\
0 & 0 & 100 & 0 & 0 & 2
\end{array}
$$

$\begin{array}{rrrrrr}0 & 32 & 0 & 0 & 100 & 2 \\ 0 & 5 & 66 & 0 & 8 & 95 \\ 9 & 27 & 0 & 0 & 8 & 79 \\ 0 & 69 & 66 & 0 & 24 & 100 \\ 0 & 3 & 8 & 0 & 0 & 54 \\ 0 & 88 & 0 & 8 & 100 & 2 \\ 100 & 3 & 66 & 23 & 20 & 100 \\ 9 & 10 & 66 & 15 & 100 & 100 \\ 0 & 5 & 0 & 0 & 0 & 100 \\ 0 & 5 & 0 & 0 & 4 & 97\end{array}$


Table 3 (cont.)

No. of strains $\quad$...

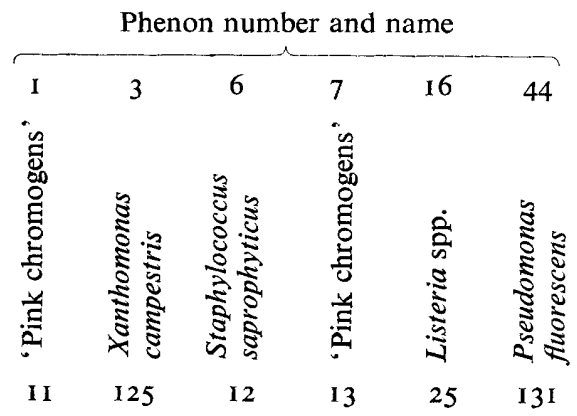

Sole carbon source (at $2 \mathrm{~g} \mathrm{l}^{-1}$ ):

Cis-aconitic acid

Adonitol

DL- $\alpha$-Alanine

$\mathbf{L}(-)$-Arabinose

$D(-)$-Arabinose

$\mathrm{L}(-)$-Arginine. $\mathrm{HCl}$

Calcium lactate

Capric acid

Caproic acid

Caprylic acid

Cellobiose

Chlorogenic acid

meso-Erythritol

Ethanol

$\mathrm{D}(-)$-Fructose

$\mathrm{D}(-)$-Galactose

D(-)-Glucose

Glycerol

$\mathrm{L}(-)$-Histidine. $\mathrm{HCl}$

p-Hydroxybenzoic acid

Inositol

Inulin

Lactose

L(-)-Leucine

Maltose

Mannitol

Mannose

Melezitose

DL-Norleucine

Pelargonic acid

L(-)-Proline

Putrescine

Raffinose

Ribose

Salicin

DL-Serine

Sodium acetate

Sodium benzoate

Sodium butyrate

Sodium citrate

Sodium formate

Sodium fumarate

Sodium gluconate

Sodium glutamate

Sodium malate

Sodium malonate

Sodium oxalate

Sodium pyruvate

Sodium succinate

\begin{tabular}{|c|c|c|c|c|c|}
\hline 9 & 0 & 0 & 0 & 0 & 45 \\
\hline 0 & 0 & 0 & 0 & 40 & 100 \\
\hline 0 & 0 & 0 & 0 & 4 & 100 \\
\hline 100 & I & 0 & 15 & 100 & 100 \\
\hline 9 & I & 0 & 0 & 0 & 3 \\
\hline 0 & 0 & 0 & 0 & 0 & 100 \\
\hline 73 & 3 & 0 & 0 & 0 & 100 \\
\hline 100 & 0 & 0 & 0 & 0 & 100 \\
\hline 0 & 0 & 0 & 0 & 0 & 95 \\
\hline 0 & 0 & 0 & 0 & 0 & 2 \\
\hline 9 & 20 & 0 & 0 & 100 & 2 \\
\hline 18 & 0 & 0 & 0 & 0 & 0 \\
\hline 0 & 3 & 0 & 0 & 40 & 100 \\
\hline 100 & 3 & 0 & 8 & 0 & 6 \\
\hline 0 & 10 & 0 & 8 & 100 & 100 \\
\hline 100 & 6 & 0 & 0 & 28 & 100 \\
\hline $9 \mathrm{I}$ & 96 & 66 & 0 & 100 & 100 \\
\hline 100 & 64 & 0 & 0 & 100 & 100 \\
\hline 0 & 2 & 0 & 0 & 0 & 100 \\
\hline 0 & 2 & 0 & 0 & 0 & 100 \\
\hline 0 & 2 & 0 & 8 & 0 & 100 \\
\hline 0 & 2 & 0 & 0 & 96 & 77 \\
\hline 0 & 0 & 0 & 0 & 96 & 0 \\
\hline 0 & 3 & 0 & 8 & 0 & 100 \\
\hline 0 & 3 & 0 & 8 & 20 & 9 \\
\hline 0 & 5 & 0 & 0 & 100 & 100 \\
\hline 0 & 5 & 0 & 0 & 100 & 100 \\
\hline 0 & 3 & 0 & 0 & 40 & 6 \\
\hline 0 & 0 & 0 & 0 & 0 & 4 \\
\hline 0 & 0 & 0 & 0 & 0 & 100 \\
\hline 0 & 48 & 0 & 0 & 64 & 77 \\
\hline 0 & 0 & 0 & 0 & 0 & I 8 \\
\hline 0 & 3 & 0 & 0 & 100 & 0 \\
\hline 0 & 6 & 0 & 8 & 48 & 100 \\
\hline 0 & 0 & 0 & 0 & 100 & 0 \\
\hline 0 & 0 & 0 & 0 & 0 & 100 \\
\hline 100 & 2 & 0 & 8 & 0 & 92 \\
\hline 0 & 0 & 0 & 0 & 0 & 6 \\
\hline 9 & 0 & 0 & 0 & 0 & 100 \\
\hline 100 & 3 & 0 & 0 & 96 & 100 \\
\hline 36 & 0 & 0 & 8 & 0 & 38 \\
\hline 100 & 2 & 0 & 23 & 48 & 100 \\
\hline 9 I & $5^{8}$ & 0 & 0 & 100 & 100 \\
\hline 100 & 2 & 0 & 46 & 92 & 92 \\
\hline 100 & 0 & 0 & 54 & 100 & 100 \\
\hline 100 & 2 & 0 & 38 & 0 & 95 \\
\hline 0 & 0 & 0 & 0 & 0 & I \\
\hline 100 & 2 & 0 & 8 & 0 & 100 \\
\hline 100 & 3 & 0 & 46 & 100 & 98 \\
\hline
\end{tabular}


Table 3 (cont.)

\begin{tabular}{|c|c|c|c|c|c|c|}
\hline & 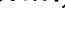 & Phenc & n numl & and & me & \\
\hline & 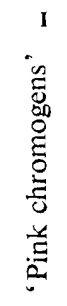 & 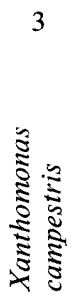 & 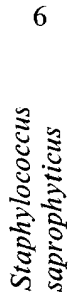 & 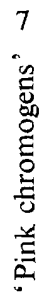 & 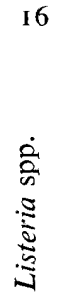 & 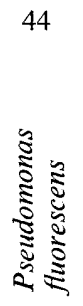 \\
\hline No. of strains $\quad \ldots$ & I I & 125 & 12 & 13 & 25 & I3I \\
\hline Sodium tartrate & 0 & 0 & 0 & 15 & 0 & I \\
\hline Sorbitol & 0 & 3 & 0 & 0 & 92 & 95 \\
\hline Spermine $.4 \mathrm{HCl}$ & 0 & 3 & 0 & 0 & 0 & 92 \\
\hline Sucrose & 0 & 3 & I7 & 0 & 100 & 100 \\
\hline Trehalose & 0 & I6 & 0 & 0 & 100 & 100 \\
\hline DL-Tryptophan & 0 & 0 & 0 & 0 & 0 & 56 \\
\hline $\mathrm{L}(-)$-Tyrosine & 0 & 2 & 0 & 0 & 0 & 100 \\
\hline DL-Valine & 0 & 2 & 0 & 0 & 0 & 100 \\
\hline$D(+)-X y l o s e$ & 0 & 3 & o & 0 & 100 & 92 \\
\hline
\end{tabular}

Negative characters common to the phenetic groups. Colony characteristics: Central colonial bodies, Dry-granular, Rhizoidal, Spreading, Green, Orange, Red, Violet, Pyocyanin. Stained preparations: Mycelium, Pleomorphism. Biochemical tests: Indole production, Methyl red, Phenylalanine deaminase, VogesProskauer. Degradation of: Cellulose, Sodium hippurate. Growth at $42{ }^{\circ} \mathrm{C}$. Utilization as sole carbon source: Pimelic acid, Starch.

NCPPB2226 and $X$. hederae NCPPB2336. Since the last two are subjective synonyms of $X$. campestris (Dye \& Lelliott, 1974) this name was preferred for phenon 3 isolates. Strains were Gram-negative rods, $<2 \mu \mathrm{m}$ long, producing yellow, mucoid colonies on GYEA. Motility, when recorded, was by means of a single polar flagellum. Glucose was attacked oxidatively, or not at all, and most isolates were oxidase-negative, did not reduce nitrate, and did not decarboxylate arginine, lysine or ornithine. Most strains produced levan, degraded starch and gelatin, grew at $10{ }^{\circ} \mathrm{C}$, but utilized only glucose, glycerol and sodium gluconate of the sole carbon sources tested (Table 3).

Phenon 6 contains $\mathrm{I} 1$ isolates and Pseudomonas melophthora NCPPB42. However, our culture of the latter was a fermentative Gram-positive coccus showing few of the properties expected for pseudomonads (Stanier, Palleroni \& Doudoroff, 1966). The isolates were identified as Staphylococcus saprophyticus by their colonial and micromorphology, ability to ferment glucose and inability to degrade starch or aesculin or decarboxylate ornithine (Cowan \& Steel, 1965; Baird-Parker, 1974a, b). The strains grew at $37^{\circ} \mathrm{C}$ in the presence of $5 \%(\mathrm{w} / \mathrm{v})$ sodium chloride; most grew on glucose as sole carbon source but, apart from sucrose, no other sole carbon source supported growth (Table 3).

Phenon 7 contains 13 pink chromogens which could not be identified using the diagnostic schemes. In many respects, the strains resembled those in phenon I except that they generally did not readily degrade any of the organic compounds tested or grow on the various sole carbon sources tested (Table 3 ).

Phenon 16 contains 25 isolates tentatively identified as Listeria (Seeliger \& Welshimer, I974) by their morphology and ability to degrade aesculin, and by their inability to produce indole or hydrolyse casein, gelatin and urea. The organisms were Gram-variable rods, $<2 \mu$ m long, motile by means of a few peritrichous flagella, forming yellow colonies on GYEA. Glucose and lactose were attacked fermentatively, starch and Tween 20 were degraded but nitrate was not reduced. Growth occurred in $2 \%(\mathrm{w} / \mathrm{v})$ sodium chloride, at 5 and $10{ }^{\circ} \mathrm{C}$ and on a wide range of sole carbon sources including $\llcorner(-)$-arabinose, cello- 
biose, $\mathrm{D}(-)$-fructose, $\mathrm{D}(-)$-glucose, glycerol, inulin, lactose, mannitol, mannose, raffinose, salicin, sodium citrate, sodium gluconate, sodium glutamate, sodium malate, sodium succinate, sorbitol, sucrose, trehalose and $\mathrm{D}(+)$-xylose.

Phenon 44 includes I 25 isolates and the six reference strains of Pseudomonas fluorescens. The isolates were Gram-negative, oxidative rods, motile by means of a single polar flagellum, forming colonies which exhibited the fluorescent, diffusible pigment fluorescein. In addition, the strains were oxidase-positive, decarboxylated arginine, degraded casein, gelatin, tributyrin, Tweens 20 and 80 , and tyrosine and utilized malonate and a wide range of compounds as the sole source of carbon and energy (Table 3). They also grew at 5 and $10{ }^{\circ} \mathrm{C}$ and in the presence of $5 \%(\mathrm{w} / \mathrm{v})$ sodium chloride. This cluster was identified as $P$. fluorescens on the basis of the properties listed above and the inclusion of the marker strains.

\section{Minor phena}

Twenty-six per cent of the phylloplane isolates were recovered in the 45 minor phena. The characteristics of these are listed in tables which can be obtained from the senior author. The unidentified phena were mainly labelled on the basis of pigmentation (Fig. I); the identified taxa are considered below.

Only two Gram-positive spore-bearing rods were found, forming phenon 5. However, they could not be identified further with the keys of Gordon et al. (1973).

Yellow Gram-negative, oxidase-negative, fermentative rods, generally exhibiting gliding motility (Perry, 1973) but not degrading cellulose or chitin were identified as Flexibacter species (Leadbetter, 1974). These isolates were recovered in phenon 8 and in phena 17 to 25. However, most flexibacteria were recovered in two aggregate clusters defined at or above the $70 \% \mathrm{~S}$ level (Fig. I). Flavobacterium aquatile NCIB8694 and Flavobacterium pectinovorum NCIB9059 were recovered in phena 8 and 24 respectively. However, the status of these species is not clear for the reference strains exhibit gliding motility (Weeks, 1974; Goodfellow et al., 1976b) and should not be classified in the genus Flavobacterium. Most of the flexibacteria grew at 5 and $10{ }^{\circ} \mathrm{C}$ and on a wide range of sole carbon sources (Table 5).

Phena 26 to 37 contain Gram-positive or Gram-variable, fermentative, non-sporing, irregular or pleomorphic rods, provisionally labelled 'coryneform' bacteria. Most of the 'coryneform' taxa fell into one of three aggregate clusters defined at or above the $75 \% \mathrm{~S}$ level (Fig. I). Corynebacterium betae NCPPB375 was recovered in phenon 28. Chemotaxonomic (Keddie \& Cure, 1977) and numerical phenetic data (Jones, 1975) indicate that $C$. betae should be reclassified in the coryneform taxon Curtobacterium (Yamada \& Komagata, 1972). The 'coryneform' bacteria grew at $10{ }^{\circ} \mathrm{C}$, most degraded aesculin, tributyrin and Tweens 20 and 80 and utilized a wide range of sole carbon sources.

Phena 39 and 45 contain short, non-motile, oxidative, Gram-negative rods which are oxidase-negative and were identified as Acinetobacter spp. (Lautrop, I974; Reyn, 1974; Pagel \& Seyfried, I976).

Phenon 40 contains four strains loosely associated with Pseudomonas maltophila NCIB9204, NCTCIO257 and Pseudomonas multivorans NCIB9085. The isolates were Gram-negative, nonfluorescent, polarly flagellated, oxidative rods, able to degrade aesculin, casein, gelatin, lecithin, tributyrin, Tweens 20 and 80 and utilize a wide range of carbon compounds as the sole source of carbon and energy. The phenon appears to be intermediate between $P$. maltophila and $P$. multivorans (Stanier et al., 1966) and may represent an undescribed species.

Phenon 42 contains five isolates, Chromobacterium typhi-flavum NCTC938I and Erwinia herbicola NCPPB656. Strains were Gram-negative, fermentative rods, motile by means of 3 to 6 peritrichous flagella, able to reduce nitrate and utilize a wide range of carbon compounds as the sole source of carbon and energy. The strains in phenon 43 , which shared 
Table 4. Distinguishing characters for the six major phena

Phenon number and name

\begin{tabular}{|c|c|c|c|c|c|}
\hline I & 3 & 6 & 7 & I 6 & 44 \\
\hline 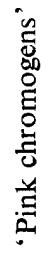 & 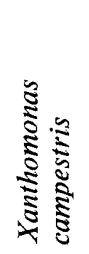 & 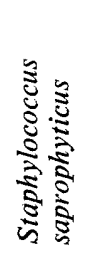 & 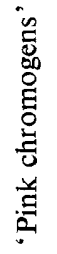 & 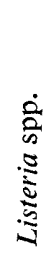 & 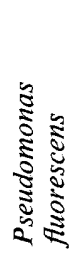 \\
\hline II & 125 & 12 & I3 & 25 & 131 \\
\hline
\end{tabular}

Colonial characters:

Minute $(<\mathrm{I} \mathrm{mm})$

Mucoid

Pigment

Fluorescent diffusible pigment

Stained preparations:

Gram stain
Micromorphology

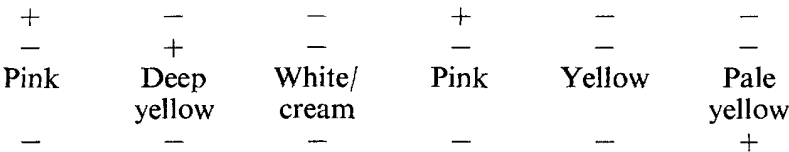

$\begin{array}{cccccc}- & - & + & - & d & - \\ \text { Long } & \text { Short } & \text { Coccus } & \begin{array}{c}\text { Long } \\ \text { rod }\end{array} & \begin{array}{c}\text { Short } \\ \text { rod }\end{array} & \begin{array}{c}\text { Short } \\ \text { rod }\end{array}\end{array}$

Biochemical tests:

Oxidation (o)/Fermentation (F)

Arginine dihydrolase

Gluconate oxidation

Malonate utilization

Oxidase

$\begin{array}{cccccc}\text { ol- } & \text { o/ } & \text { F } & \text { o/ } & \text { F } & \text { o } \\ + & \text { d } & - & + & - & + \\ - & - & - & - & - & + \\ + & - & - & \text { d } & - & + \\ - & \text { d } & - & - & - & +\end{array}$

Degradation of:

Aesculin

Starch

Tributyrin

Tween 20

Tween 80

Tyrosine

Tolerance to:

$\mathrm{NaCl}(2 \%, w / v)$

$\mathrm{NaCl}(5 \%, \mathrm{w} / \mathrm{v})$

Growth at:

$37^{\circ} \mathrm{C}$

Sole carbon source (at $2 \mathrm{~g} \mathrm{1}^{-1}$ ):

Adonitol

DL- $\alpha$-Alanine

L(-)-Arabinose

$\mathrm{L}(-)$-Arginine. $\mathrm{HCl}$

Capric acid

Caproic acid

Cellobiose

meso-Erythritol

Ethanol

D(-)-Fructose

$\mathrm{D}(-)$-Galactose

D(-)-Glucose

Glycerol

$\mathrm{L}(-)$-Histidine. $\mathrm{HCl}$

p-Hydroxybenzoic acid

Inositol

Inulin

Lactose

L(-)-Leucine 
Table 4 (cont.)

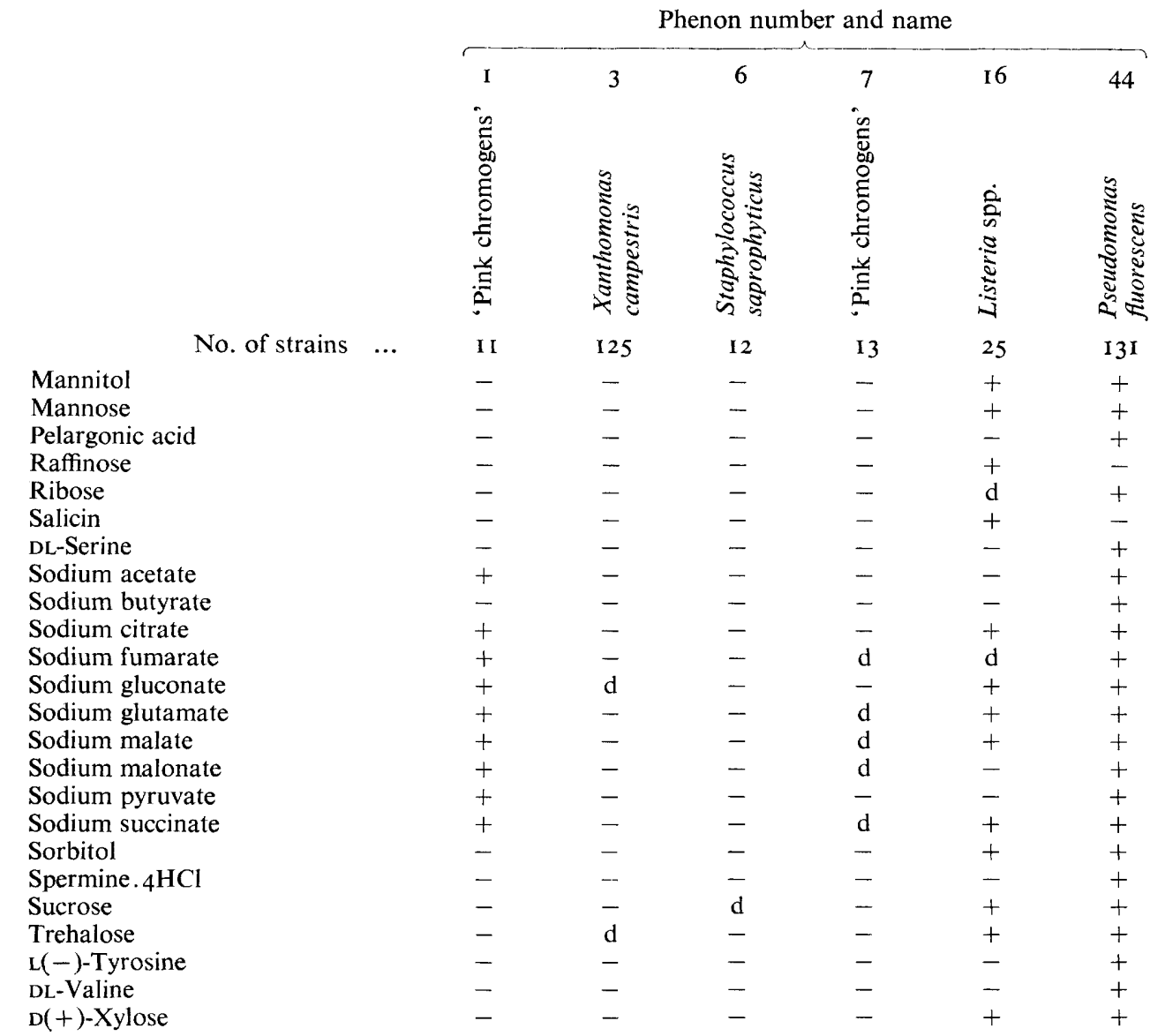

+ , More than $90 \%$ of strains positive; - more than $90 \%$ of strains negative; d, strains II to $89 \%$ positive.

a similarity of over $80 \%$ with $E$. herbicola (Fig. I), were identified as Klebsiella spp. These isolates were Gram-negative, non-motile, fermentative rods, Voges-Proskauer-positive and, like E. herbicola, used a wide range of carbon compounds for energy and growth. The two strains forming phenon 47 were identified as Micrococcus luteus (Baird-Parker, I974c) and those in phenon 50 as Staphylococcus spp. (Baird-Parker, 1974a).

\section{Miscellaneous isolates}

Twenty-six per cent ( 165 ) of the isolates were not recovered in any of the phena defined at or above the $80 \% \mathrm{~S}$ level. The unclassified strains included 22 Gram-positive cocci, 2 actinomycetes and 12 pseudomonads (Stanier et al., 1966), one of which fitted the description of Pseudomonas cepacia (Palleroni \& Doudoroff, 1972). The remaining isolates were Gram-negative rods, 2I of which were related to the 'pink chromogens' of phena I and 7 .

Characters associated with the phena

Characters potentially useful for the discrimination of the phena are shown in Tables 4 and 5 . 
Table 5. Diagnostic table for the identification of the minor phena

\begin{tabular}{|c|c|c|c|c|c|c|c|c|c|c|c|c|c|c|c|c|c|c|c|c|c|}
\hline & $\stackrel{*}{\Xi}$ & 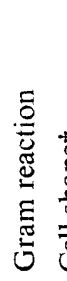 & 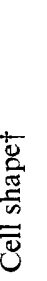 & 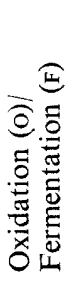 & 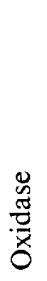 & 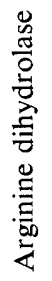 & 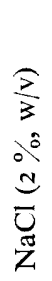 & 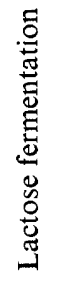 & 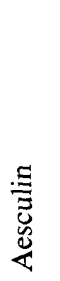 & 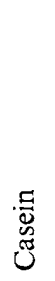 & $\frac{\Xi}{\stackrel{\Xi}{\Xi}}$ & & 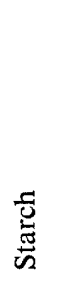 & 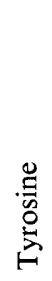 & 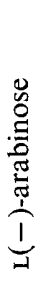 & 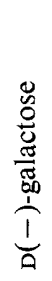 & $\begin{array}{l}\overline{0} \\
\stackrel{0}{0} \\
\stackrel{\Xi}{0}\end{array}$ & 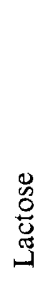 & $\begin{array}{l}\stackrel{\mathscr{O}}{\Xi} \\
\frac{\mathscr{\Xi}}{\pi} \\
\sum\end{array}$ & 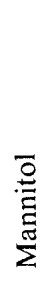 & $\frac{2}{t}$ \\
\hline 2 & $\mathrm{p}$ & - & $r$ & o & - & + & - & - & - & - & - & - & D & - & - & - & + & D & D & - & - \\
\hline 4 & c & - & $r$ & o & + & - & - & - & + & - & - & - & - & + & - & - & - & + & - & - & + \\
\hline & w & + & $r$ & o & D & - & D & 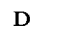 & - & - & - & - & - & - & - & - & - & - & - & - & - \\
\hline 0 & $y$ & - & $r$ & $\mathrm{~F}$ & - & - & - & - & - & - & - & - & - & - & + & + & - & - & + & - & - \\
\hline 9 & $\mathrm{c} / \mathrm{py}$ & - & $\mathrm{r}$ & F & - & - & D & - & + & - & - & - & + & - & - & - & - & - & - & $\mathrm{D}$ & - \\
\hline & py & - & $\mathrm{r}$ & o & - & - & - & - & - & - & - & D & + & - & - & - & - & - & - & - & D \\
\hline & $y$ & - & $\mathrm{r}$ & $F$ & - & - & + & - & + & - & - & - & + & - & - & - & - & - & + & - & - \\
\hline & $y$ & - & $r$ & 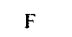 & - & 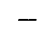 & + & - & + & D & - & - & + & - & + & - & - & + & - & + & + \\
\hline & $w / c$ & - & $r$ & O & - & - & - & 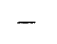 & - & - & - & - & - & - & - & - & + & - & + & + & + \\
\hline & $y$ & - & $r$ & 0 & - & - & 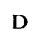 & & $\mathrm{D}$ & + & + & - & D & - & $\mathrm{D}$ & - & + & - & + & + & 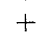 \\
\hline & 0 & - & $r$ & o & - & - & $\mathrm{D}$ & & + & - & - & - & - & - & - & - & + & - & - & & - \\
\hline & py & + & $r$ & $F$ & - & - & + & + & + & - & + & - & + & - & + & - & - & $\mathrm{D}$ & 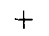 & & + \\
\hline & py & + & $r$ & F & - & - & + & + & D & - & + & - & D & - & + & + & - & + & $T$ & & r \\
\hline & $y$ & $+1-$ & $\mathrm{r}$ & F & - & - & + & 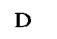 & + & - & + & $\mathrm{D}$ & + & - & + & + & $\mathrm{D}$ & + & + & + & + \\
\hline 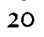 & py & - & $r$ & 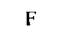 & - & - & + & & - & - & D & - & 0 & - & + & + & 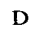 & + & & & + \\
\hline & $\mathrm{y}$ & + & $r$ & o & - & - & + & + & $\mathrm{D}$ & D & - & - & - & - & + & + & - & + & $T$ & & + \\
\hline 2 & $y$ & - & $r$ & 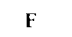 & - & - & - & - & + & - & D & - & - & + & + & + & - & D & + & - & 1 \\
\hline 23 & $y$ & - & $r$ & F & - & - & - & D & + & - & . & - & D & $\mathrm{D}$ & + & + & - & + & . & 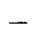 & 1 \\
\hline 24 & $y$ & - & $r$ & 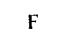 & - & - & - & - & + & - & - & - & - & - & + & $\mathrm{D}$ & - & D & $T$ & - & + \\
\hline 23 & $y$ & - & $r$ & 1 & + & - & $\mathrm{D}$ & - & + & - & D & - & 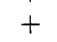 & - & + & + & - & + & & & r \\
\hline 26 & $\mathrm{y}$ & - & $r$ & $c$ & - & 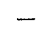 & + & + & . & + & - & - & & - & + & + & & & & & \\
\hline 27 & 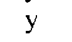 & - & $\mathrm{r}$ & c & - & - & + & & + & - & - & - & I & - & & t & & & & & \\
\hline 28 & $y$ & $+1-$ & $r$ & $\mathrm{~F}$ & - & - & + & + & $\mathrm{D}$ & + & - & - & D & - & + & + & + & $T$ & & & + \\
\hline 29 & $y / 0$ & - & $r$ & 2 & - & - & + & $\mathrm{D}$ & + & + & + & + & $t$ & - & + & + & D & $\mathrm{D}$ & + & + & T \\
\hline 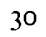 & . & - & $r$ & $\mathbf{F}$ & - & - & + & D & + & + & - & + & 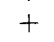 & - & + & - & + & - & - & - & 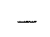 \\
\hline 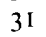 & c & + & $r$ & o & - & 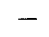 & + & + & + & D & + & - & + & - & + & + & D & D & + & + & + \\
\hline 3 & W & + & $r$ & 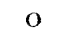 & - & - & + & + & - & - & - & - & - & - & + & + & + & + & + & + & + \\
\hline & 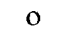 & - & $\mathrm{r}$ & I & - & - & - & - & + & - & - & - & $t$ & - & + & - & - & - & & - & + \\
\hline & o & - & $\mathrm{r}$ & & - & - & + & - & + & - & - & - & 2 & - & + & + & - & + & & 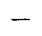 & + \\
\hline & 0 & - & $\mathrm{r}$ & $\mathrm{F}$ & - & - & - & - & D & - & - & - & 7 & - & + & $\mathrm{D}$ & - & + & & 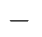 & + \\
\hline 3 & o & - & $r$ & 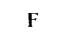 & - & - & - & + & D & - & - & - & $t$ & - & $t$ & $\mathbf{D}$ & - & - & & - & + \\
\hline & o & - & $r$ & 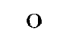 & - & - & - & - & - & - & - & - & - & - & + & + & - & + & & - & 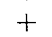 \\
\hline & $\mathrm{v}$ & - & $\mathrm{r}$ & $c$ & + & + & - & + & 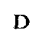 & - & - & - & 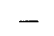 & - & + & + & - & + & + & - & - \\
\hline & 1 & - & $\mathrm{r}$ & & - & - & J & + & $\mathbf{D}$ & - & - & & & - & + & - & 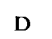 & - & & & - \\
\hline & py & - & $\mathrm{r}$ & & - & - & + & - & + & + & + & & & + & - & & - & + & & - & + \\
\hline & $y$ & - & $r$ & F & - & - & + & - & + & - & - & - & & - & - & & - & + & & & T \\
\hline 4 & 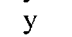 & - & $\mathrm{r}$ & 1 & - & - & $f$ & $\mathrm{~T}$ & $\mathrm{D}$ & $\mathrm{D}$ & - & & - & - & & & + & - & & & + \\
\hline 7 & w & - & $\mathrm{r}$ & F & - & - & + & + & + & - & - & - & - & - & + & + & - & + & + & 1 & $t$ \\
\hline 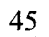 & $\mathrm{p}$ & - & $\mathrm{r}$ & 0 & - & + & + & - & $D$ & $\cdots$ & - & - & & - & + & + & - & + & + & + & + \\
\hline 40 & $\mathrm{y}$ & - & $\mathrm{r}$ & F & - & - & + & - & - & $\mathrm{D}$ & + & + & + & - & $T$ & + & + & + & - & 1 & + \\
\hline 47 & $y$ & + & $\mathrm{c}$ & o & - & - & + & - & - & - & - & - & - & - & + & + & + & + & + & $t$ & $T$ \\
\hline 48 & py & - & $r$ & o & - & $\mathrm{D}$ & + & - & - & - & - & - & - & - & + & + & - & - & + & + & + \\
\hline 49 & $\mathrm{y}$ & $+1-$ & $r$ & 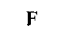 & - & - & + & 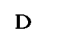 & + & - & $\mathrm{D}$ & - & + & D & + & + & D & † & + & + & + \\
\hline 8 & $y$ & + & $\mathrm{c}$ & $\mathrm{F}$ & - & - & + & $D$ & + & $\mathbf{D}$ & $D$ & D & + & D & D & $D$ & D & $\mathrm{D}$ & + & + & \\
\hline & py & - & $\mathrm{r}$ & o & - & - & + & - & - & + & + & + & - & + & - & D & D & - & + & - & \\
\hline
\end{tabular}

+ , More than $80 \%$ of strains positive; - less than $20 \%$ of strains positive; D, 21 to $79 \%$ of strains positive.

* c, cream; o, orange; $p$, pink; py, pale yellow; w, white; y, yellow.

$\dagger \mathrm{r}$, rods; c, cocci. 
Table 6. Temporal distribution of the major phena

Results indicate the numbers of isolates, out of the total of 621 , of each taxon recorded on each date. Numbers in parentheses indicate the frequency of each taxon as a percentage of the total isolate on each date.

\begin{tabular}{|c|c|c|c|c|c|}
\hline \multirow[t]{2}{*}{ 政 } & \multicolumn{4}{|c|}{ Distribution in 1973} & \multirow{2}{*}{$\begin{array}{l}\% \text { of } \\
\text { total strains } \\
\text { examined }\end{array}$} \\
\hline & I6 May & I I July & 5 September & 3 I October & \\
\hline $\begin{array}{l}\text { 'Pink chromogens' } \\
\text { (phenon I) }\end{array}$ & $100(\mathrm{II})$ & 0 & 0 & 0 & $\mathrm{I} \cdot 7$ \\
\hline $\begin{array}{l}\text { Xanthomonas } \\
\text { campestris (phenon 2) }\end{array}$ & $32(28)$ & I6 (I4) & $46(40)$ & $6(5)$ & $19 \cdot 4$ \\
\hline $\begin{array}{l}\text { Staphylococcus } \\
\text { saprophyticus (phenon 6) }\end{array}$ & 0 & 0 & $22(2)$ & $78(7)$ & $\mathrm{I} \cdot 8$ \\
\hline $\begin{array}{l}\text { 'Pink chromogens' } \\
\text { (phenon } 7 \text { ) }\end{array}$ & $80(8)$ & $20(2)$ & o & 0 & $2 \cdot I$ \\
\hline Listeria spp. (phenon I6) & 0 & 0 & $20(4)$ & $80(\mathrm{I} 6)$ & $4 \cdot 0$ \\
\hline $\begin{array}{l}\text { Pseudomonas } \\
\text { fluorescens (phenon 44) }\end{array}$ & o & $100(55)$ & 0 & I (I) & $20 \cdot 0$ \\
\hline Total no. phena & 10 & 13 & 16 & 20 & \\
\hline
\end{tabular}

\section{General characteristics of the isolates}

All of the test strains were catalase-positive, did not produce hydrogen sulphide, oxidize alcohol, degrade cellulose, chitin, sodium hippurate or urea, or utilize adipic acid, geraniol, pimelic acid, urea or valeric acid as sole carbon sources.

Most of the strains were Gram-negative rods $(90 \%)$, pigmented $(81 \%)$, mainly yellow $(58 \%)$, grew at $5{ }^{\circ} \mathrm{C}(6 \mathrm{I} \%)$ and $10{ }^{\circ} \mathrm{C}(75 \%)$ but not at $37{ }^{\circ} \mathrm{C}(12 \%)$ and $42{ }^{\circ} \mathrm{C}(\mathrm{I} \%)$. Approximately half of the strains were motile, mainly pseudomonads with polar flagella, and about half degraded aesculin (4I \%), casein $(50 \%)$, gelatin $(39 \%)$, tributyrin $(64 \%)$, Tween $20(58 \%)$ and Tween $80(60 \%)$. Fewer degraded starch $(28 \%)$ or reduced nitrate $(19 \%)$. Mainly negative results were recorded for the Voges-Proskauer $(2 \%)$, methyl red $(2 \%)$, indole $(2 \%)$ and phenylalanine deaminase $(2 \%)$ tests.

The majority of strains produced acid from glucose, $45 \%$ aerobically and $25 \%$ anaerobically. Nearly all of the sugars and carbon sources tested were attacked by at least some of the cultures: $\mathrm{L}(-)$-arabinose $(60 \%)$, fructose $(70 \%)$, galactose $(55 \%)$, glycerol $(58 \%)$, mannitol $(53 \%)$, mannose $(68 \%)$, sodium gluconate $(60 \%)$, sodium malate $(58 \%)$, sucrose $(59 \%)$, trehalose $(61 \%)$ and xylose $(61 \%)$ were most frequently utilized; $\mathrm{D}(-)$ arabinose $(8 \%)$, caprylic acid $(4 \%)$, chlorogenic acid $(8 \%)$, DL-norleucine $(4 \%)$, pimelic acid $(4 \%)$, sodium benzoate $(6 \%)$, sodium succinate $(2 \%)$, sodium tartrate $(3 \%)$ and starch $(3 \%)$ were only sparingly used.

\section{Temporal distribution of the isolates}

The diversity of the bacteria isolated from the phylloplane of Lolium perenne increased progressively throughout the sampling period (Table 6). Xanthomonas campestris occurred consistently on both newly expanded and ageing leaves throughout the season. The other relatively common taxa were only isolated in any quantity on one or two occasions. This suggests that either the composition of the populations was rapidly shifting, which may be correlated with large increases in total numbers (Dickinson et al., 1975), or alternatively the sampling system may have been inadequate to cover spatial variations in the leaf populations. Support for the former conclusion comes from the similarity between the September and October populations which were from leaves of two different positions on the plants. 


\section{DISCUSSION}

The present findings reinforce the view that numerical taxonomic methods can effectively record variation in large unknown mixed populations of bacteria. If the bacterial flora of natural habitats contains strains with independent and correlated characters then taxometric methods can be used to detect and define representative samples of the constituent taxa. In this first numerical phenetic survey of leaf surface bacteria, $74 \%$ of the Lolium isolates were recovered in six major and 45 minor phena. There was sufficient consistency within, and differences between, phena for characters to be extracted from the data and weighted for identification.

It is now realized that test errors can distort similarity coefficients (Sneath \& Johnson, 1972) and that even 'standard' tests are not always reliable (Sneath \& Collins, I974). However, in ecological studies some taxonomic principles may sometimes be overlooked so that additional isolates can be studied. In this survey, test error and reproducibility studies were not done; omissions which should be made good in future investigations. Nevertheless, the recovery of well-defined and homogeneous phena suggests that test error was within acceptable limits. Only 17 of the marker strains $(25 \%)$ were recovered in defined phena and even then only four phena were identified. This result, like those from previous studies (Goodfellow et al., 1976a), merely illustrates the difficulties in selecting strains for the identification of taxa in analyses of large mixed populations of bacteria. However, as more becomes known of the species composition of the leaf surface flora, the easier the choice of marker strains will become. Clearly, future studies on leaf surface bacteria should include good representatives of the genera Acinetobacter, Corynebacterium, Curtobacterium, Flexibacter, Listeria, Micrococcus, Pseudomonas, Staphylococcus, Xanthomonas and of less well established taxa containing yellow chromogens (Goodfellow et al., I $976 b$ ). Phena which do not contain marker strains are often identified using conventional keys (Pfister \& Burkholder, 1965; Lowe \& Gray, 1972); however, this expedient can be of limited value, as in the present study, for distinct phena can be keyed out to the same taxon. These difficulties emphasize that natural habitats may contain bacteria that previously either went unrecognized or were 'dumped' into heterogeneous groups after a cursory examination of a few 'important' characters.

Nearly half of the Lolium isolates were identified as Pseudomonas fluorescens, Staphylococcus saprophyticus, Xanthomonas campestris, Listeria spp. or as pink chromogens (clusters I and 7). Although it is difficult to compare numerical phenetic classifications with those based on only a few subjectively chosen characters, it should be noted that Stout (I960) recorded large numbers of Pseudomonas spp., Xanthomonas spp. and pink chromogens (flavobacteria) from Lolium leaves. Pseudomonas fluorescens strains have been isolated from the leaves of Phaseolus vulgaris L. (Teliz-Ortiz \& Burkholder, 1960), Fagus (Jensen, I97I), Prunus spp. (Barclay \& Crosse, I974) and Pinus (Goodfellow et al., 1976a) and seem to be indigenous to leaf surfaces. Listeriae are widely distributed in nature (Gregorio \& Eveland, 1975) and both Listeria monocytogenes and Listeria murrayi have been isolated from decaying vegetation (Welshimer \& Meredith, 197I; Welshimer \& Donker-Voet, I97I; Weiss \& Seeliger, I975). Unlike L. monocytogenes strains those from Lolium were not haemolytic, did not degrade Tween 80 or produce acetoin and can be provisionally allotted to the L. grayi/murrayi group (Seeliger \& Welshimer, 1974). There are no previous reports of Staph. saprophyticus or X. campestris from the phylloplane but it is likely that such strains have been misclassified in the past. Pink, Gram-negative, motile rods with a polar flagellum have been found in association with plant material (Billing, 1976) and, like representatives of some of the minor clusters, need further study.

It seems that at any one time only a few bacterial species predominate on the leaf surface. Thus, xanthomonads and pink chromogens formed large populations in May but were replaced by listeriae and staphylococci by October. Jensen (1971) noted that fluorescent 
pseudomonads were common on Fagus leaves during early summer but declined rapidly in August, when large numbers of non-pigmented rods were found. The reasons for such fluctuations are not known but they may reflect changes in the nutrient regime, moisture, temperature and other ecological parameters. These findings parallel the situation that has been determined for the fungal community in these habitats (Dickinson \& Wallace 1976) and they suggest that the phylloplane is a very selective habitat for microbial growth. The recovery of large populations of Xanthomonas campestris throughout the growing season suggests that they form part of the indigenous flora of Lolium leaves. The ability of these strains to produce extracellular levan in vitro may be significant since phytopathogenic pseudomonads often produce polysaccharide lgums that block the vessels of susceptible hosts (Agrios, I969). In general, phylloplane isolates are proficient in utilizing sugars, sugar alcohols and inorganic salts as sole sources of carbon for energy and growth; fructose, galactose, glucose and sucrose have been detected in leaf exudates (Tukey, I97I) and may be important to phylloplane bacteria in vivo.

Despite their spatial proximity, leaves, litter and soil apparently contain independent bacterial communities with specific properties (Hissett \& Gray, 1974). It is evident from this and earlier work (Goodfellow et al., I976a,b) that phylloplane bacteria are predominantly Gram-negative, chromogenic rods, many of which can be identified as Pseudomonas and Xanthomonas. Pigmentation may confer resistance to ultraviolet radiation in sunlight (Mathews \& Sistrom, I960) or desiccation (Grinstead \& Lacey, 1973). By contrast the soil flora generally includes large populations of Gram-positive, non-chromogenic bacteria classified as Arthrobacter, Bacillus and Streptomyces (Stout, 1960; Goodfellow, 1969; Jensen, 197I; Holm \& Jensen, 1972; Lowe \& Gray, 1972) though Gram-negative bacteria are common in some grassland soils (Stout, 196I) and in the rhizosphere (Rovira \& Brisbane, 1967). Bacteria on litter may occupy an intermediate position. Hissett \& Gray (1974) recovered large populations of Arthrobacter and Pseudomonas from Fraxinus and Quercus litter.

Little is known of the significance of this bacterial flora to the plant or to other indigenous leaf surface micro-organisms. However, the numerical classification of the bacterial flora of Lolium perenne leaves has made it possible to select strains objectively for interaction studies. Thus, representative strains have been shown to be antagonistic to Drechslera dictyoides (Drechsler) Shoemaker, the agent of net blotch disease of $L$. perenne (Austin et al., I977). Similarly, the highlighting of characters for the identification of phylloplane bacteria will make it possible to monitor bacterial populations on green and senescent leaves and their responses to seasonal factors, to pathogen damage and to man-made factors, such as fertilizers and pesticides.

The authors thank Dr J. R. Leece for his invaluable help with the computation and Dr D. Jones for helpful consultation. B.A. thanks the Natural Environment Research Council for a Research Studentship.

Additional data regarding the characteristics of isolates in the minor phena may be obtained from B.A.

\section{REFERENCES}

Agrios, G. N. (1969). Plant Pathology. New York: Academic Press.

Austin, B., Dickinson, C. H. \& Goodfellow, M. (1977). Antagonistic interactions of phylloplane bacteria with Drechslera dictyoides (Drechsler) Shoemaker. Canadian Journal of Microbiology 23, 710-715.

BaIRD-PARKer, A. C. (I974a). Family I. Micrococcaceae Pribram 1929, 385. In Bergey's Manual of Determinative Bacteriology, 8th edn, pp. 478-
479. Edited by R. E. Buchanan and N. E. Gibbons. Baltimore: Williams \& Wilkins.

BAIRD-PARKer, A. C. (1974b). Staphylococcus Rosenbach 1884, I8 nom. cons. Opin. I7 Jud. Comm. 1958, 153. In Bergey's Manual of Determinative Bacteriology, 8th edn, pp. 483-489. Edited by R. E. Buchanan and N. E. Gibbons. Baltimore: Williams \& Wilkins.

Baird-PARKer, A. C. (1974c). Genus I. Micrococcus Cohn I872, I5I. In Bergey's Manual of 
Determinative Bacteriology, 8th edn, pp. 478-483. Edited by R. E. Buchanan and N. E. Gibbons. Baltimore: Williams \& Wilkins.

Barclay, G. A. \& Crosse, J. E. (1974). Populations of aerobic bacteria associated with the roots of apple and cherry plants. Journal of Applied Bacteriology 37, 475-486.

Billing, E. (1976). The taxonomy of bacteria on the aerial parts of plants. In Microbiology of Aerial Plant Surfaces, pp. 223-273. Edited by C. H. Dickinson and T. F. Preece. London: Academic Press.

Buchanan, R. E. \& Gibbons, N. E. (editors) (1974). Bergey's Manual of Determinative Bacteriology, 8th edn. Baltimore: Williams \& Wilkins.

CowAN, S. T. \& STEEL, K. J. (1965). Manual for the Identification of Medical Bacteria. Cambridge: Cambridge University Press.

Dickinson, C. H. \& Wallace, B. (i976). Effects of late applications of foliar fungicides on activity of micro-organisms on winter wheat flag leaves. Transactions of the British Mycological Society 76, 103-I I 2 .

Dickinson, C. H., Austin, B. \& Goodfellow, M. (1975). Quantitative and qualitative studies of phylloplane bacteria from Lolium perenne. Journal of General Microbiology 9x, I 57-166.

Dye, D. W. \& LellotT, R. A. (1974). Xanthomonas Dowson 1939, 187. In Bergey's Manual of Determinative Bacteriology, 8th edn, pp. 243-249. Edited by R. E. Buchanan and N. E. Gibbons. Baltimore: Williams \& Wilkins.

GoODFELLOW, M. (1969). Numerical taxonomy of some heterotrophic bacteria isolated from a pine forest soil. In The Soil Ecosystem, pp. 83-105. Edited by J. G. Sheals. Systematics Association Publication no. 8. London: The Systematics Association.

Goodfellow, M., Austin, B. \& Dawson, D. $(\mathrm{I} 976 \mathrm{a})$. Classification and identification of phylloplane bacteria using numerical taxonomy. In Microbiology of Aerial Plant Surfaces, pp. 275292. Edited by C. H. Dickinson and T. F. Preece. London: Academic Press.

Goodfellow, M., Austin, B. \& Dickinson, C. H. $(1976 \mathrm{~b})$. Numerical taxonomy of some yellow pigmented bacteria isolated from plants. Journal of General Microbiology 97, 219-233.

Gordon, R. E., Haynes, W. C. \& Pang, C. H.-N. (1973). The Genus Bacillus. Agricultural Handbook no. 427. Washington, DC: Agricultural Research Service, United States Department of Agriculture.

Graham, P. H. (1964). The application of computer techniques to the taxonomy of root nodule bacteria of legumes. Journal of General Microbiology 35, 5 I I-517.

Gregorio, S. B. \& Eveland, W. C. (1975). Isolation of Listeria monocytogenes from inapparent sources in Michigan. In Problems of Listeriosis, pp. 87-93. Edited by M. Woodbine. Leicester: University Press.

Grinsted, J. \& LAcEY, R. W. (1973). Ecological and genetic implications of pigmentation in Staphylococcus aureus. Journal of General Microbiology 75, 259-267.

HissetT, R. \& GrAy, T. R. G. (I974). Bacterial populations of litter and soil in a deciduous woodland. I. Qualitative studies. Revue d'écologie et de biologie du sol 10, 495-508.

Holm, E. \& JENSEN, V. (1972). Aerobic chemoorganotrophic bacteria of a Danish beech forest. Oikos 23, 248-260.

Hucker, G. L. \& ConN, H. J. (I923). Methods of Gram staining. Technical Bulletin, New York State Agricultural Experiment Station, no. 93.

JENSEN, V. (I97I). The bacterial flora of beech leaves. In Ecology of Leaf Surface Micro-organisms, pp. 463-469. Edited by T. F. Preece and C. H. Dickinson. London: Academic Press.

Jones, D. (1975). A numerical taxonomic study of coryneform and related bacteria. Journal of General Microbiology 87, 52-96.

KedDIE, R. M. \& Cure, G. L. (1977). The cell wall composition and distribution of free mycolic acids in named strains of coryneform bacteria and in isolates from various natural sources. Journal of Applied Bacteriology 42, 229-252.

KING, E. O., Ward, M. K. \& Raney, D. E. (1954). Two simple media for the demonstration of pyocyanin and fluorescein. Journal of Laboratory and Clinical Medicine 44, 30I-307.

LAST, F. T. \& WARREN, R. C. (1972). Non-parasitic microbes colonizing green leaves: their form and functions. Endeavour 31, I43-150.

Lautrop, H. (1974). Acinetobacter Brisou and Prévot 1954, 727. In Bergey's Manual of Determinative Bacteriology, 8th edn, pp. 436-438. Edited by R. E. Buchanan and N. E. Gibbons. Baltimore: Williams \& Wilkins.

LeADBETTER, E. R. ( 1974). Cytophaga Winogradsky 1929, 577; Lewin 1969, 191. Emend. mut. char. In Bergey's Manual of Determinative Bacteriology, 8th edn, pp. IOI-I05. Edited by R. E. Buchanan and N.E. Gibbons. Baltimore: Williams \& Wilkins.

Leben, C. \& DAFT, G. C. (1965). Influence of an epiphytic bacterium on cucumber anthracnose, early blight of tomato and northern leaf blight of corn. Phytopathology 55, 760-762.

Lowe, W. E. \& Gray, T. R. G. (1972). Ecological studies on coccoid bacteria in a pine forest soil. I. Classification. Soil Biology and Biochemistry 4, 459-467.

Lowe, W. E. \& Gray, T. R. G. (1973a). Ecological studies on coccoid bacteria in a pine forest soil. II. Growth of bacteria inoculated into soil. Soil Biology and Biochemistry 5, 449-462.

Lowe, W. E. \& GRAY, T. R. G. (1973b). Ecological studies on coccoid bacteria in a pine forest soil. III. Competitive interactions between bacterial strains in soil. Soil Biology and Biochemistry $\mathbf{5}$, 463-472.

McMeekin, T. A., Stewart, D.B. \& Murray, J. G. (1972). The Adansonian taxonomy and the deoxyribonucleic acid base composition of some Gram-negative, yellow pigmented rods. Journal of Applied Bacteriology 35, I 29-I 37.

Mathews, M. M. \& Sistrom, W. R. (I960). The function of the carotenoid pigments of Sarcina lutea. Archiv für Mikrobiologie 35, 139-146.

Pagel, J. E. \& Seyfried, P. L. (1976). Numerical taxonomy of aquatic Acinetobacter isolates. Journal of General Microbiology 95, 220-232. 
Palleroni, N. J. \& Doudoroff, M. (I972). Some properties and taxonomic subdivisions of the genus Pseudomonas. Annual Review of Phytopathology I0, 73-100.

Perry, L. B. (1973). Gliding motility in some nonspreading flexi-bacteria. Journal of Applied Bacteriology 36, 227-232.

Pfister, R. M. \& BUrkholder, P. R. (I965). Numerical taxonomy of some bacteria isolated from antarctic and tropical seawaters. Journal of Bacteriology 90, 863-872.

Reichelt, J. L. \& BaumanN, P. (1973). Taxonomy of the marine luminous bacteria. Archiv für Mikrobiologie 94, 283-330.

Reyn, A. (1974). Family I. Neisseriaceae Prévot 1933, I I9. In Bergey's Manual of Determinative Bacteriology, 8th edn, pp. 427-432. Edited by R. E. Buchanan and N. E. Gibbons. Baltimore: Williams \& Wilkins.

Rovira, A. D. \& Brisbane, P. G. (1967). Numerical taxonomy and soil bacteria. In The Ecology of Soil Bacteria, pp. 337-350. Edited by T. R. G. Gray and D. Parkinson. Liverpool: Liverpool University Press.

Rustigan, R. \& Stuart, C. A. (I94I). Decomposition of urea by Proteus. Proceedings of the Society for Experimental Biology and Medicine 47, 108 .

Seeliger, H. P. R. \& Welshimer, H. J. (I974). Listeria. In Bergey's Manual of Determinative Bacteriology, 8th edn, pp. 593-596. Edited by R. E. Buchanan and N. E. Gibbons. Baltimore: Williams \& Wilkins.

Shimwell, J. L., Carr, J. G. \& Rhodes, M. E. (1960). Differentiation of Acetomonas and Pseudomonas. Journal of General Microbiology 23, 283286.

SneAth, P. H. A. (1957). The application of computers to taxonomy. Journal of General Microbiology 17, 201-226.

Sneath, P. H. A. \& Collins, V. G. (1974). A study in test reproducibility between laboratories: report of a Pseudomonas working party. Antonie van Leeuwenhoek 40, 48I-527.

SNeAth, P. H. A. \& Johnson, R. (1972). The influence on numerical taxonomic similarities of errors in microbiological tests. Journal of General Microbiology 72, 377-392.

SNeath, P. H. A. \& SOKal, R. R. (1973). Numerical Taxonomy. London: W. H. Freeman.

Sokal, R. R. \& Michener, C. D. (1958). A statistical method for evaluating systematic relationships. Kansas University Science Bulletin 38, 1409-I 438. Soumare, S., Losfield, J. \& Blondeau, R. (I973).
Apports de la taxonomie numerique a l'étude du spectre bactérien de la microflore des sols du nord de la France. Annales de Microbiologie (Institut Pasteur) 124B, 8 I-97.

Stanier, R. Y. (1942). The cytophaga group: a contribution to the biology of myxobacteria. Bacteriological Reviews 6, $143^{-196 .}$

Stanier, R. Y., Palleroni, N. J. \& Doudoroff, M. (1966). The aerobic pseudomonads: a taxonomic study. Journal of General Microbiology 43, 159$27 \mathrm{I}$.

Stout, J. D. (1958). Biological studies of some tussock-grassland soils. IV. Bacteria. New Zealand Journal of Agricultural Research r, 943-957.

Stout, J. D. (1960). Biological studies of some tussock-grassland soils. XV. Bacteria of two cultivated soils. New Zealand Journal of Agricultural Research 3, 214-223.

STouT, J. D. (I96I). A bacterial survey of some New Zealand forest lands, grasslands and peats. New Zealand Journal of Agricultural Research 4, I-30.

Teliz-Ortiz, M. \& Burkholder, W. H. (1960). A strain of Pseudomonas fluorescens antagonistic to $P$. phaseolicola and other bacterial plant pathogens. Phytopathology 50, I I9-123.

TukEY, H. B. (1971). Leaching of substances from plants. In Ecology of Leaf Surface Micro-organisms, pp. 67-80. Edited by T.F. Preece and C. H. Dickinson. London: Academic Press.

DE VRIES, J. T. \& DeRX, H. G. (I953). On the occurrence of Mycoplana rubra and its identity with Protaminobacter ruber. Annales bogoriensis 1, 5360 .

WeEks, O. B. (1974). Genus Flavobacterium Bergey et al. 1923, 97. In Bergey's Manual of Determinative Bacteriology, 8th edn, pp. 357-364. Edited by R. E. Buchanan and N. E. Gibbons. Baltimore: Williams \& Wilkins.

Weiss, J. \& Seeliger, H. P. R. (1975). Incidence of Listeria monocytogenes in nature. Applied Microbiology 30, 29-32.

Welshimer, H. J. \& DONKER-Voet, J. (I97I). Listeria monocytogenes in nature. Applied Microbiology 2x, 5I 6-5I 9.

Welshimer, H.J. \& Meredith, A. L. (I97I). Listeria murrayisp.n.: a nitrate-reducing mannitolfermenting Listeria. International Journal of Systematic Bacteriology 21, 3-7.

Yamada, K. \& Komagata, K. (1972). Taxonomic studies on coryneform bacteria. V. Classification of coryneform bacteria. Journal of General and Applied Microbiology 18, 4I 7-43I. 